\title{
Semiotics and Its Application in Pohutu Aadati Lihu Lo Limu Devices in Gorontalo
}

\author{
Sance A. Lamusu \\ Gorontalo State University \\ Email: sancelamusu@yahoo.com
}

\begin{abstract}
This article is a preliminary research on pohutu aadati lihu lo limu, 'customary ceremonial devices of lemon bath' which focuses on sign and sign system $\mathrm{f}$ language existing in the cultural device. It can be concluded that there are sign and sign system of language based on relation between expression and content (ERC) and sign system of language which is based on the relation of reality and its basic kinds such as icons, indices, and symbols ([R]-[O]-[ I]. Sign and sign system [E]$[\mathrm{R}]-[\mathrm{C}]$ have forms like $[\mathrm{R}]$ between $\mathrm{E}$ and $\mathrm{C}$ : that the development of meaning and change to the secondary or connotative direction $[\mathrm{C}]$ only once occurs in expression $[\mathrm{E}]=(\mathrm{E}-\mathrm{R}-\mathrm{C})$; in case the event the development of meaning and change to the secondary or connotative direction [C] occurs several times $(6 \mathrm{x})$ in the expression [E], the form will be like the relation of [R] E(E-R1-C; E-R2-C; E-R3-C; E-R4-C; E-R5-C; E-R6-C] C. The meaning development of such form of sign and sign system both at the level of first-primary (denotative) and the level of second-secondary (connotative) occurs several times in [E]. It can be said that the meaning development at the level of first-primary (denotative) is synonymous with form indices and icons and the meaning development at the level of second-secondary (connotative) is synonymous with symbols.
\end{abstract}

Keywords: sign, sign system, primary, secondary

\section{INTRODUCTION}

Gorontalo tribe is an ethnic community whose culture is actualized through their foundations of life. One of the Gorontalo tribe's culture is Pohutu Aadati Lihu Lo Limu' Lemon Bath Customary Ceremony'. Pohutu Aadati Lihu Lo Limu is a custom believed by Gorontalo tribe as Islamization and self-care for Gorontalo women starting since their childhood to adulthood. Such customary ceremony is one of the traditional aspects of birth custom which applied in every girl aged 1-3 years. Pohutu Aadati Lihu Lo Limu consists of three implementation stages and each implementation stage has cultural device as a complement to perfection or validity of the ceremony. The first stage is mongubingo or mongulu'o 'female circumcision'. The second stage is mopolihu lo limu 'bathing with fragrant water or lemon water'. The third stage is mopohuta'a to pingge 'setting foot on seven dishes'. The interesting problem to study is sign and sign system in the cultural device used in Pohutu Aadati Lihu Lo Limu.

Semiotics studies systems, rules, and conventions that allow signs to have meaning or significance (Preminger et al. via Pradopo, 1999: 76). According to Saussure (1988: 26), semiotics is the study of signs in a society in which signs occur on any things and rules govern them. The relation of sign is emphasized on the need for social convention. According to Eco (2009: 22), sign is something based on social conventions that have been previously existed, can be treated as something that represents something else. Sign can mean something for someone if such 'meaningful' 
relation is mediated by an interpretant. According to Peirce (via Hawkes, 1978: 132), every sign certainly has two levels, namely linguistic level and mythical level. Linguistic level is a full primary signifier because the signifier has fixed meaning reference. Word or language is a signifier that refers to the denotative meaning of the signified. In contrast, secondary signifier (at the mythical level) is a full sign at the linguistic level poured into an empty signifier. The following the example of Peirce's classification.

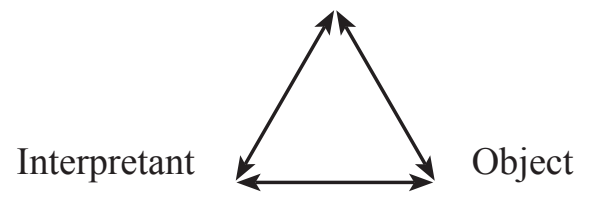

\section{Peirce's TriadicScheme}

An interpreter is someone whose position is as a researcher, an analyst and a reviewer of an object comprehended through three lines of logic, namely the relation between logic and the signifier type (qualisign, sinsign, legisign), the relation between reality and its basic type (icon, index and symbol), and the relation between mind and the signified type of (rheme or seme, dicent or dicisign or pheme,argument) (via E. Innis, 1985: 7-9; Santosa, 1993: 10-11). Man in his life sees a sign through two axes, namely the syntagmatic axis (juxtaposition of sign) and paradigmatic axis (associative) (Hoed, 2014: 20). The concept of syntagmatic and paradigmatic is the first concept developed by Barthes (2007: 82) and the second concept is denotation and connotation.

Based on the aforementioned explanation, this research on the device of Pohutu Aadati Lihu Lo Limu which focuses on sign and sign system is analyzed in accordance with convention and structure of Gorontalo society. Data supporting this research are data obtained from the field through three stages, namely informants interviewed and social situation observed in relation to the focus of the research, further sample selection in order to expand the description of information and to trace the possible variation of information, and to stop the further sample selection when variation of information are not found anymore. The samples of informants are taken following the procedure proposed by Spradley (1980: 15) through five criteria, namely (1) informants who had been long and intensive in living together with the field of activity serving as the information, (2) informants who were still fully engaged/active in the activity in which the researcher was interested, (3) informants who had enough time to be interviewed, (4) informants did not tend to process or prepare in advance in giving information, and (5) it could be determined that informants were still "unfamiliar" with the research. A method used in collecting data was snowball sampling. This method is like a rolling snowball, initially small and gradually becoming bigger and bigger (Sugiyono, 2009: 85). Data in this research were analyzed qualitatively, consisting of three simultaneous stages, namely data reduction, data presentation, and conclusion (Miles and A. Michael Huberman, 2009: 16).

\section{THEORY OF SEMIOTICS AND ITS APPLICATION}

In the view of Saussure and Barthes, the role of semiotics in cultural studies is obvious because sign and sign system is based on conventions and rules from the society. According to Peirce, semiotics is directed more on the understanding of how human knowledge to understand things around him, both social environment and universe. On the other hand, Eco states that sign is a cultural unit in the form of symbol consisting of various types, including index and icon that represent symbol. Eco admits that the sign production is a physical activity, and the sign signifies something important. According to Culler (via Pradopo, 1995: 44), an important and meaningful sign takes the form of icon, index, and symbol. The signs have meaning based on system, rule, or convention.

In general, the theory of semiotics can be distinguished into theory of signs that are dichotomous and trichotomous or dyadic and triadic. Saussure (1988) examines sign dichotomously consisting of signifiant (form/ signifier) and signifie (meaning/signified). The form referred to is the sound of the language, but the image of the sound. For example, chess game. Every chess piece can be regarded as a signifier and line allowed for every chess piece is the signified. "Knight" moves on "L" line, "bishop" moves "diagonally" in a straight line, "king" can move in any direction in one vacant square, and so on. The chess piece itself is regarded as the image of form 
or the image of view because not all chess pieces of "knight" have the same size or made of the same material, but have the same features and the same movement.

Barthes (1980: 67) uses the theory of signifiant and signifie which is developed into a theory of metalanguage and connotation. The term signifiant becomes expression [E] and signifie becomes content or meaning [C]. However, Barthes says that there should be certain relation [R] between $\mathrm{E}$ and $\mathrm{C}$ so as to create sign [Sn]. This is a structural concept proposed by Saussure. However, the concept of relation [R] makes the theory of sign is developed further because $\mathrm{R}$ is determined by the user of the sign. [E] can develop and create a new sign that there is more than one signifier with the same C. This development is called metalanguage and forms what is called "synonymy". Every sign always obtain initial meaning generally known as denotation and called primary system by Barthes and the development of secondary system towards $\mathrm{E}$ is called metalanguage. The secondary system toward $\mathrm{C}$ is called connotation, that is the development of content [C] of an expression [E]. The concept of connotation is not only based on cognitivism, but also pragmatism, i.e. the user of sign and the situation for understanding. For example, for a particular group, the flag of the United States (US) is not simply the flag of a country. In the primary system, the Relation [R] is between $\mathrm{E}$ (the concept of the US flag) and C (one of the symbols that represent the US), but for certain circles with their secondary system the development of $\mathrm{C}$ takes place, such as "the symbol of an aggressor state" or "the symbol of a terrorist state". Therefore, R between E and C changes in the secondary system. This is a symptom of connotation that appears more clearly after the collapse of the World Trade Center Towers in New York in September 2001 and the US invasion to Afghanistan.

Semiotic theory, according to Peirce, states that all natural and cultural phenomena should be regarded as signs. He developed a sign model, namely triadic or trichotomous model, a process of understanding signs that follows the relation between the three points consisting of representamen [R], object [O], and interpretant [I]. $\mathrm{R}$ is part of the sign that can be perceived physically or mentally which refers to something represented by him [O], and [I] is part of the process of interpreting the relation between $\mathrm{R}$ and O. Therefore, sign is not only representative, but also interpretative. For example, if someone is walking somewhere seeing smoke rising in the distance [R], the source of the smoke is (factory's chimney) [O]. Then, it is interpreted it is already close to the car tire factory. Such interpretation is called index. If someone sees a portrait of a car, $[\mathrm{R}]$ refers to an [O]. In the next process, the interpretation is a green saloon car as his own car [I]. The process of such sign interpretation is called icon, that the relation between $\mathrm{R}$ and $\mathrm{O}$ indicate identity. In addition, another example, if on the beach someone sees a red flag [R], the concept of his knowledge refers to the prohibition of swimming [O]. The next interpretation is that it is dangerous to swim in that place [I], so that the sign is called symbol, that the relation between $\mathrm{R}$ and $\mathrm{O}$ is conventional, meaning that one must understand the convention regarding the relation between the "red flag" and "prohibition of swimming" (in Hoed, 2014: 57-60).

Figure 1

Pollutube, Totabu/Alama,Taluhu Ngohalati wau Tohetutu

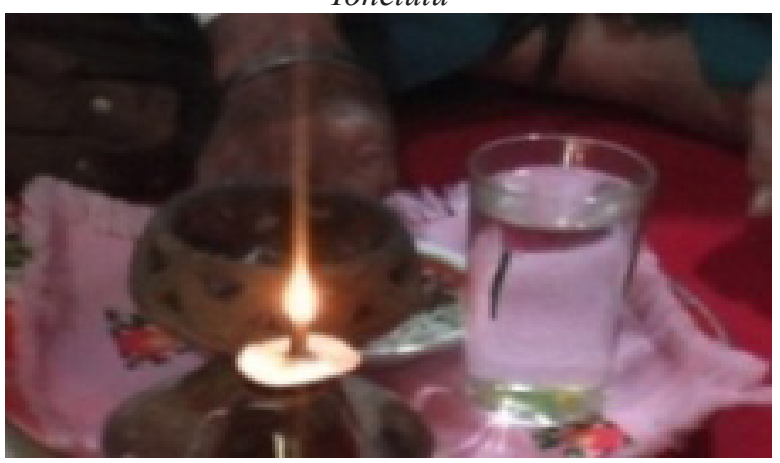

\section{FORMS OF SIGN AND SIGN SYSTEM}

The research on the sign and sign system of the Pohutu Aadati Lihu Lo Limu device Pohutu Aadati Lihu Lo Limu found the forms of sign and its system through the relation [R] between the expression [E] and the content or the development towards connotative or secondary sign [C], and the process of sign interpretation is also done by applying the relation between the three points, namely representamen [R], object [O], and interpretant [I]. 


\section{Devices in the stage of Mongubingo/Mongulu'o 'Circumcision'}

\section{(1) Tohetutu 'Traditional Lamp'}

Figure 1 shows three objects that accompany tohetutu, namely taluhu ngohalati 'a glass of water', pollutube 'a place forcinders' and totabu/ alama 'incense'. However, what is described in Figure 1 is only tohetutu. Tohetutu is a lamp used by the ancestors of Gorontalo [E] - [R]. If the ancestors held traditional ceremonies in the evening, tohetutu was used because it was not easily blown out by the wind although it was not as bright as electric lamp or Coleman lamp. Tohetutu is made from tree sap. Every Ramadan tohetutu is used to celebrate the culture of hui lo tumbilotohe 'night of turning onthe light' on the night of the 27, 28, 29 of Ramadan. This activity is one of the efforts to conserve tohetutu. Due to the difficulty of obtaining tohetutu in the present time, religious leaders, traditional leaders, and community leaders agree to replace it with oil lamps or candles in every customary ceremony. If so, the shape of the lamp is not an obligation, but the important thing here is the lighting and the strength to withstand the wind $[\mathrm{C} 1]-[\mathrm{O} 1]$. In this ceremony, tohetutu is interpreted as a symbol of a ray of life, even it is said that tohetutu is like edict, advice, or guide of life [C2]-[O2]. Therefore, the form of the sign [Sn] becomes E-R-C2. (E-R1-C; E-R2-C). In a further analysis, if tohetutu $[\mathrm{R}]$ and $[\mathrm{O}]$ refer to the analysis of [C1/O1] above, the process meaning that such sign interpretation is called icon because the relationship between [R] and [O] indicates identity [I]. If [O] refers to the analysis $[\mathrm{C} 2 / \mathrm{O} 2]$ above, such sign interpretation is called symbol because the relationship between $[\mathrm{R}]$ and $[\mathrm{O}]$ is conventional [I]. The conclusion from the form of sign [Sn] of tohetutu is that there is meaning at the first-denotative (primary) level or icon, and the meaning at the second-connotative (secondary) level or symbol.

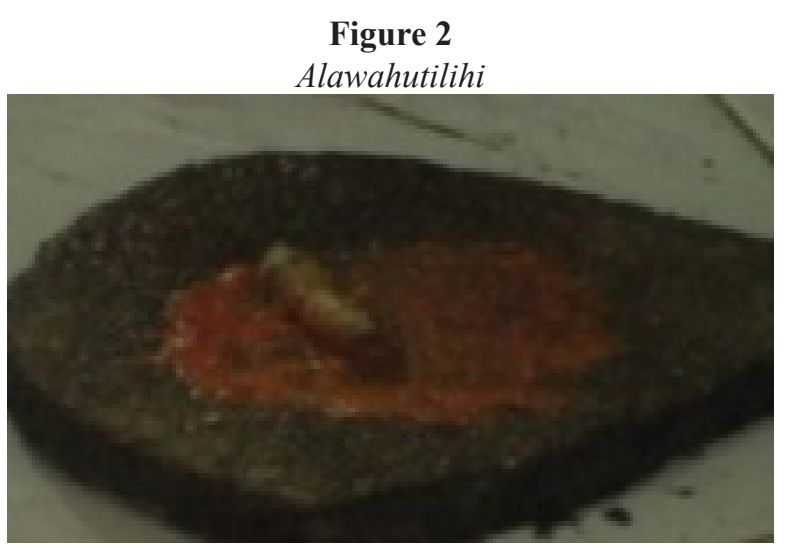

\section{(2) Alawahutilihi 'Turmeric mixed with Slacked Lime'}

Alawahutilihi is made of turmeric and slacked lime which are mashed and mixed in order to obtain a customary color of Gorontalo culture. the color in question is blood red color (see Figure 2) [E] - [R]. Alawahutilihi is made as bonto 'mark' on body parts of the child and his/her mother. Bonto is a confession of a servant to worship the Creator who promises to be a true Muslim [C1][O1]. Alawahutilihi is a symbol of pig's blood made for Bonto [C2]-[O2]. Therefore, this form of sign is E-R-C1,2 (E-R1-C; E-R2-C). In a further analysis, if alawahutilihi $[\mathrm{R}]$ and $[\mathrm{O}]$ refer to the analysis of $[\mathrm{C} 1 / \mathrm{O} 1]$ above, such sign interpretation is s called icon because the relationship between $[\mathrm{R}]$ and $[\mathrm{O}]$ indicate identity [I]. If [O] refers to the analysis of $[\mathrm{C} 2 / \mathrm{O} 2]$ above, such sign interpretation is called symbol because the relationship between $[\mathrm{R}]$ and $[\mathrm{O}]$ is conventional [I].

The conclusion from the form of sign [Sn] of alawahutilihi is that there is meaning at the first-denotative (primary) level or icon, and meaning at the second-connotative (secondary) level or symbol. One of the examples of Bonto can be seen in Figure 3. The first bonto, put on pomantowa 'forehead' is a symbol of confession that there is no other God that is worshiped other than God the Almighty. 
Figure 3

Example of Bonto

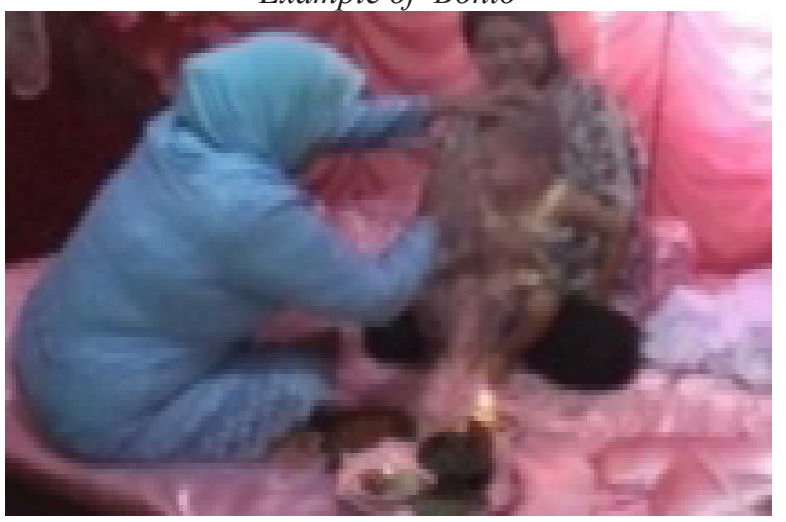

\section{(3) Paleyilulo 'Colored Rice'}

Paleyilulo is colored rice [E]-[R]. There are several views on paleyilulo. Paleyilulo consisting of five colors (see Figure 4) is an offering according to the belief of Gorontalo tribe thrown to the ceiling of the house aimed at repelling evil spirits that disrupt the lives of people living in the house [C1]-[O1].

The colors of this rice are called colors of tilabataila 'rainbow', consisting of yellow, purple (black), red, white, and green. According to the belief of Gorontalo tribe, those colors are feared by evil spirits [C2]- [O2]. Paleyilulo colors are used by Gorontalo tribe as custom colors that have symbols as follows: yellow symbolizing authority; purple symbolizing fidelity; red symbolizing courage; white symbolizing purity; and green symbolizing fertility and prosperity [C3]-[O3] Paleyilulo colors also symbolize human body [E]. Red symbolizes red blood; white symbolizes white blood; purple (black) symbolizes human flesh and also soil; yellow symbolizes marrow that exists in the human body; green symbolizes veins that exist in the human body [C4]-[O4]. Paleyilulo is a symbol of human life because rice is a source of strength of human to live [C5] - [O5]. The form of sign becomes the relation [R] between $\mathrm{E}$ and $\mathrm{C}$ (E-R-C). Changes and development occur toward secondary or connotative in $[\mathrm{E}]$, so that the form of sign of paleyilulo device becomes [R] between E and (E-R1-C; E-R2-C; E-R3-C; E-R4-C; and $\mathrm{E}-\mathrm{R} 5-\mathrm{C}) \mathrm{C} 5$ ). If paleyilulo is $[\mathrm{R}]$ and $[\mathrm{O}]$ refers to the analysis $[\mathrm{C} 1,2,3,4,5 / \mathrm{O} 1,2,3,4,5]$ above, such process of sign interpretation is called symbol, because the relationship between $[\mathrm{R}]$ and $[\mathrm{O}]$ is conventional [I]. It can be concluded that the form of sign [Sn] of paleyilulo does not meaning at the first-denotative (primary) level, but at the secondconnotative (secondary) level or symbol.

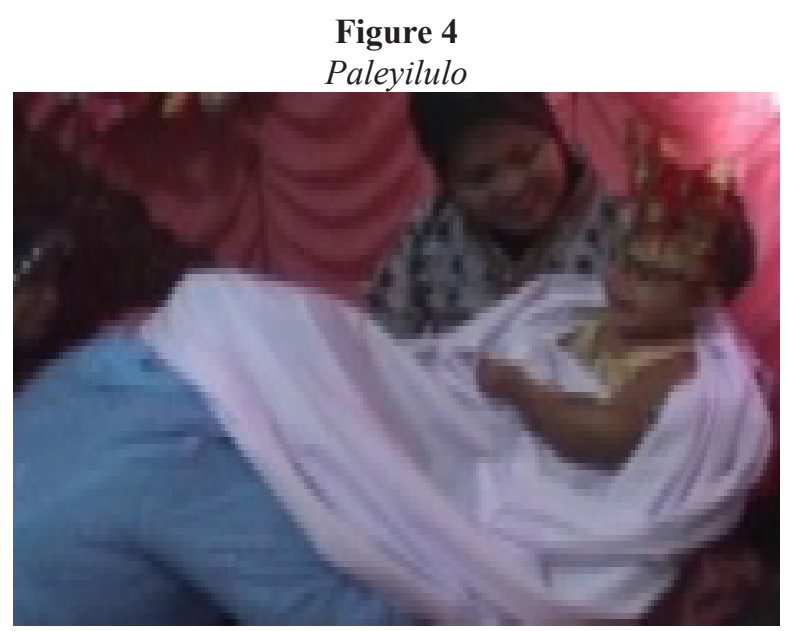

\section{(4) Alumbu 'White Fabric'}

Alumbu is used as a protective device for hulango 'village midwife' and children circumcised (see Figure 5). Alumbu measures two meters [E]$[R]$. Alumbu can function according to the context of use. For example, alumbu used by a wife whose husband had passed away functions as a skirt; alumbu used by the bride on the first night functions to perpetuate the virginity of a wife [C1]-[O1].

White fabric is a symbol of purity [C2][O2]. The development towards the secondary or connotative occurs in $[\mathrm{C}]$. Therefore, the form of alumbu sign [E] is [R] between E and (E-R1-C; $\mathrm{E}-\mathrm{R} 2-\mathrm{C}) \mathrm{C}$. If alumbu is [R] and [O] refers to the analysis of $[\mathrm{C} 1 / \mathrm{O} 1]$ above, such sign interpretation is called icon, because the relationship between [R] and $[\mathrm{O}]$ indicates identity [I]. If [O] refers to the analysis of $[\mathrm{C} 2 / \mathrm{O} 2]$ above, such sign interpretation is called symbol, because the relationship between $[\mathrm{R}]$ and $[\mathrm{O}]$ is conventional [I]. It can be concluded that the form of alumbu sign [Sn] has meaning at the first-denotative (primary) level or icon, and meaning at the second-connotative (secondary) level or symbol. 
Figure 5

Alumbu worn by the child circumcized and hulango

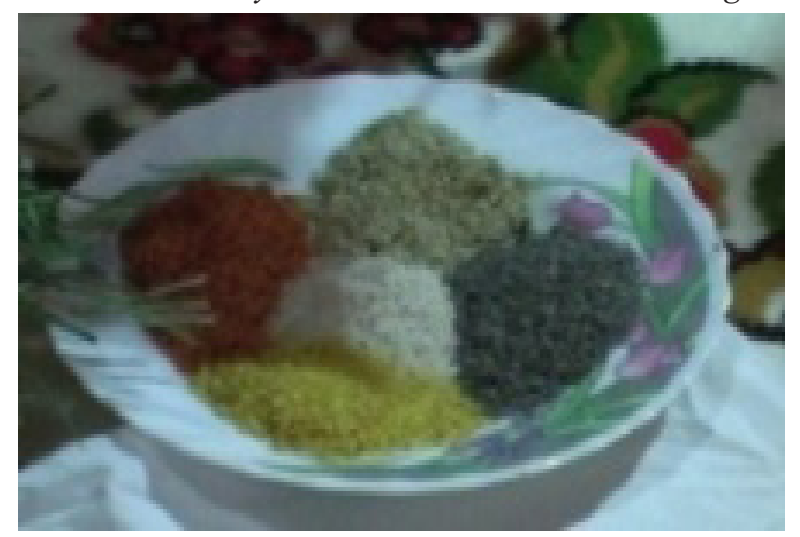

(5) Duunito 'Bamboo Knife' and Limu Tutu 'Kaffir Lime'

The ancestors of Gorontalo in mongubingo/ mongulu'o 'circumcision' used duunito that now has been replaced with a knife (see Figure 6) which is used during the circumcision [E1] - [R1].

Duunito bamboo skin is already dry. Duunito is a tool that is very cheap and sterile because it is not rusty and can be replaced at any time when needed [C]-[O]. Beside duunito, there is also a kaffir lime (see Figure 6) [E2- [R2]. Kaffir lime is used to store thing released from the genital of the child circumcised [C1]-[O1]. Kaffir lime is cut half-circle and that thing is stored in it [C2]-[O2]. Kaffir lime is selected because it tastes sour and is fragrant and serves as a remedy for cough and headache, also kills germs that cause disease in the human body [C3]-[O3]. The development towards the secondary or connotative does not occur in E1, so that the form of the sign becomes E-R-C. The development towards the secondary or connotative does not occur in E2, but occurs in C, so that the form of the sign in [E1-2] is [R] between $\mathrm{E} 1$ and C; E2 and C1,2,3 (E2-R1-C; E2-R2-C; E2-R3-C). If duuunito wau limu tutu is [R] and [O] refers to the analysis of $[\mathrm{C} / \mathrm{O}],[\mathrm{C} / \mathrm{O} 1,2,3]$, such process of sign interpretation is icon, because the relationship between [R] and [O] shows identity [I]. It can be concluded that the sign [Sn] of duunnito wau tutu limu has meaning in the first-denotative (primary) level or icon, and does not have meaning at the second-connotative (secondary) level or symbol.

\section{(6) Yilonta 'Fragrant Leaves Oil'}

Yilonta consist of turmeric leaves, pandan leaves, lime leaves, onumo leaves and other fragrant leaves. All the leaves are finely cut and mixed with coconut oil [E]-[R]. Yilonta is used to treat circumcision wounds and rubbed over the entire body of the child circumcised [C1]-[O1]. Yilonta makes the child's body fragrant [C2][O2]. The form of yilonta sign is [R] between $\mathrm{E}$ and $\mathrm{C}(\mathrm{E}-\mathrm{R}-\mathrm{C} 1,2)$. The development towards the secondary or connotative does not occur in $\mathrm{E}$ or C. If yilonta is $[\mathrm{R}]$ and $[\mathrm{O}]$ refers to the analysis of $[\mathrm{C} / \mathrm{O} 1,2]$, such process of sign interpretation is called icon, because the relationship between [R] and $[\mathrm{O}]$ indicates identity [I]. It can be concluded that the form of yilonta sign[Sn] has meaning at the first -denotative (primary) level or icon, and does not have meaning at the second-connotative (secondary) level or symbol.

Figure 6

Duunito/Pito wau Limu Tutu

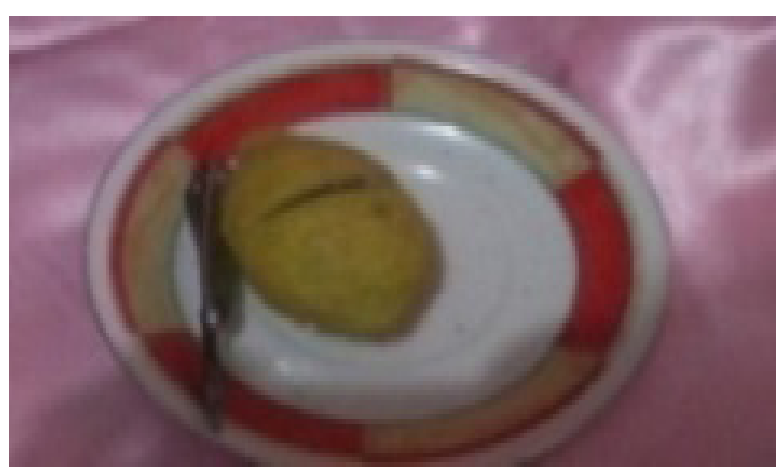

\section{DEVICES IN THE STAGE OF MOPOLIHU LO LIMU 'LEMON BATHING'}

(7) Taluhu Moonu 'Kaffir Lime Water'

Taluhu Moonu [E]-[R]. The water consists of seven ingredients, namely: 1) taluhu 'water'; 2) alipo limututu 'kaffir lime peel' which is finely sliced; 3) pitulobotu limututu 'seven limes', each of which is cut into two halves; 4) pitulodalala polohungo 'seven kinds of croton leaves'; 5) yilonta 'refined 'fragrant herb'; 6) duungo onumo 'fragrant leaves'; and 7) bunga moputi 'jasmine' (see Figure 7) [C1]-[C1]. The seven objects symbolize seven innate characters that exist in every girl, namely: (1) nene'alo 'annoying'; (2) wetetelo 
'speaking out frankly'; (3) kekengolo 'too nimble'; (4) kureketolo 'to speak as she pleases regardless of others'; (5) pa'ingolo 'like to contradict what other people say'; (6) bulabololo 'to speak aimlessly'; and (7) hutatingolo/bangganga 'rude' [C2]-[C2]. Taluhu Moonu is a symbol of the human spirit that is reflected through innate character and attitude or action [C3]-[O3]. The form of the sign becomes [R] between E and C1,2,3 (E-R1-C; E-R2-C; E-R3-C). The development towards the secondary or connotative occurs in E-R-C. If taluhu Moonu is [R] and [O] refers to the analysis of [C/O1], such process of sign interpretation is called icon, because the relationship between [R] and [O] indicates identity. If [O] refers to the analysis of $[\mathrm{C} / \mathrm{O} 1,2]$, such process of sign interpretation symbol, because the relationship between [R] and [O] is conventional [I]. It can be conclude that the form of taluhu Moonu sign [Sn] has meaning at the first-denotative (primary) level or icon, and meaning at the second-connotative (secondary) level or symbol.

Figure 7

Taluhu Moonu

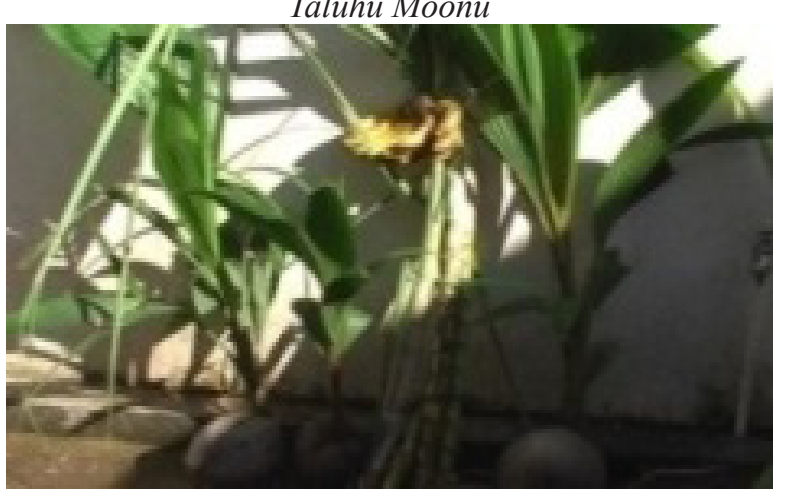

\section{(8) Patodu 'Sugarcane'}

Patodu, philosophically, is a plant that tastes sweet [E]. Patodu grows and develops easily [C1]; the stem has joints [C2]. Patodu is used as thirst-quencher and sweetener [C3]. In the past patod $u$ was used as a tool to forecast a child who would be an officer or leader when he/she were adult, based on the way he/she ate patodu. If he/ she started eating patod $u$ from the bottom, the he/ shewas not going to be a good leader, because the part he/sheate was sweet and the last part he/she ate was less sweet; if he/she ate patodu started eating from the top, he/she would a good and trustworthy leader, had conscience and knew the prevailing legal rules or norms (see Figure 8) [C4]. The form of sign becomes [R] between $\mathrm{E}$ and $\mathrm{C} 1,2,3,4$ (E-R1-C; E-R2-C; E-R3-C; E-R4-C). The development towards the secondary or connotative occurs in E-R-C. If patodu is [R] and [O] refers to the analysis of [C/O1,2,3], such process of sign interpretation is called icon, because the relationship between [R ] and [O] indicates identity [I]. If [O] refers to the analysis of [C4], such process of sign interpretation is called symbol, because the relationship between [R] and [O] is conventional [I]. It can be concluded the form of patodu sign [Sn] has meaning in the firstdenotative (primary) level or icon, and meaning at the second-connotative (secondary) level or symbol.

Figure 8

Patodu, Lutu, Tumula

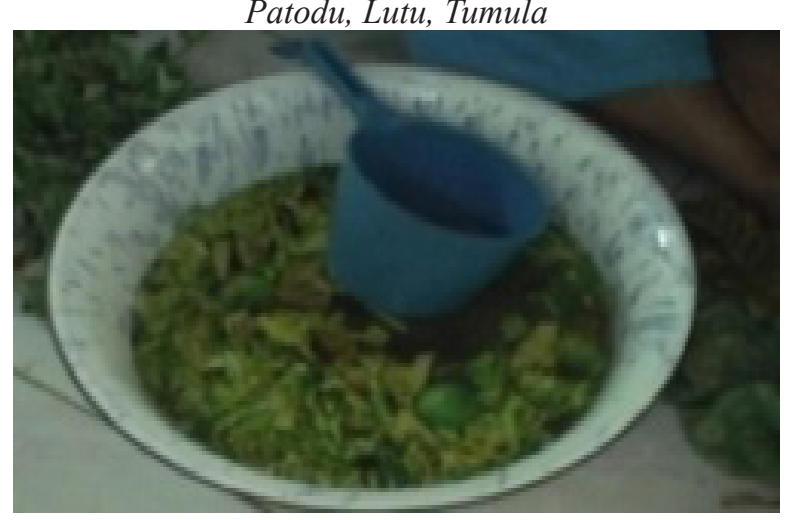

\section{(9) Lutu lo hulonti'o 'Gapi Banana'}

Lutu lo hulonti'o have the same nature as patodu, both of which have a sweet taste [E]-[R]. Both are customary devices of pohutu mopolihu lo limu because of the sweet taste. It is expected that a child is sweet towards fellow human beings [C1]-[O1], not discriminate between human beings (see Figure 8) [C2] - [O2]. Lutu lo hulonti'o is a symbol because it symbolizes a sweet heart [C3][O3]. Sweet heart for fellow human beings is the nature of lutu lo hulonti'o, its taste remains sweet, invariable, for anyone who eats it [C4]-[O4]. The form of the sign becomes [R] between $\mathrm{E}$ and C1,2,3,4 (E-R1-C; E-R2-C; E-R3-C; E-R4-C). The development towards the secondary or connotative 
occurs in E-R-C. If lutu lo hulonti'o is [R] and $[\mathrm{O}]$ refers to the analysis of [C/O1], such process of sign interpretation is called icon, because the relationship between $[\mathrm{R}]$ and $[\mathrm{O}]$ indicates identity [I]. If [O] refers to the analysis of $[\mathrm{C} / \mathrm{O} 2,3,4]$, such process of sign interpretation is called symbol, because the relationship between [R] and [O] is conventional [I]. It can be concluded that the form of lutu lo hulonti'o sign [Sn] has meaning at the first - denotative (primary) level or icon, and meaning at the second-connotative (secondary) level or symbol.

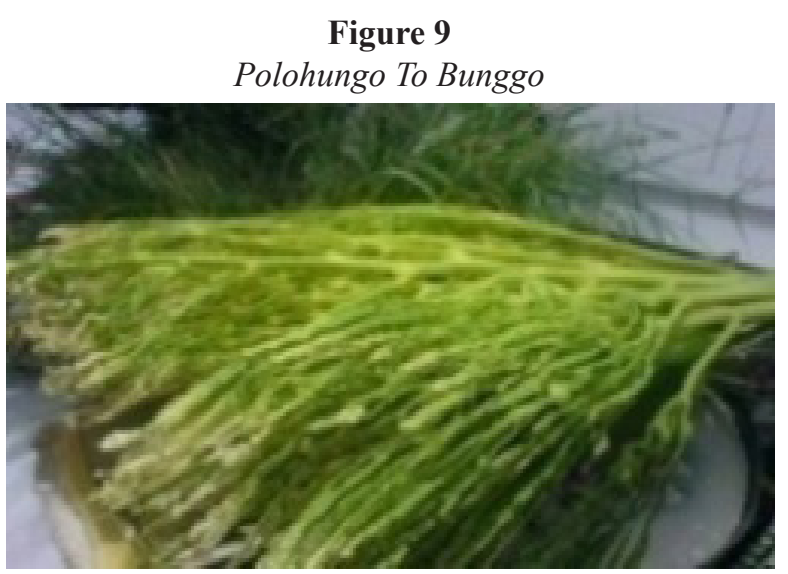

\section{(10) Tumula 'Coconut Sprout'}

Tumula [E]-[R] (see Figure 10). If planted, coconut seedling will grow into a palm tree which is very strong, not easily toppled, and long-lived [C1]-[O1]. Tumula symbolizes a strong child and will be useful for other human beings in the future [C2]-[O2]. Tumula also serves as one of the customary marriage devices that are brought together with other objects by the groom to the bride's house. In this case, tumula symbolizes the power of love that grows from the heart of a man to a woman whom he takes as his wife. Love grows like tumula that grows into a coconut tree which is very strong, stands tall and is not easily toppled as a result of hurricanes [C3] - [O]. The form of the sign becomes [R] between $\mathrm{E}$ and $\mathrm{C} 1,2,3$ (E-R1-C; E-R2-C; E-R3-C). The development towards the secondary or connotative occurs in E-R-C. Furthermore, if tumula is [R] and [O] refers to the analysis of [C/O1], such process of sign interpretation is called icon, because the relationship between $[\mathrm{R}]$ and $[\mathrm{O}]$ indicates the identity [I]. If [O] refers to the analysis of $[\mathrm{C} /$ $\mathrm{O} 2,3]$, such process of sign interpretation is called symbol, because the relationship between [R] and $[\mathrm{O}]$ is conventional [I]. It can be concluded that the form of tumula sign [Sn] has meaning at the firstdenotative (primary) level or icon, and meaning at the second-connotative (secondary) level or symbol.

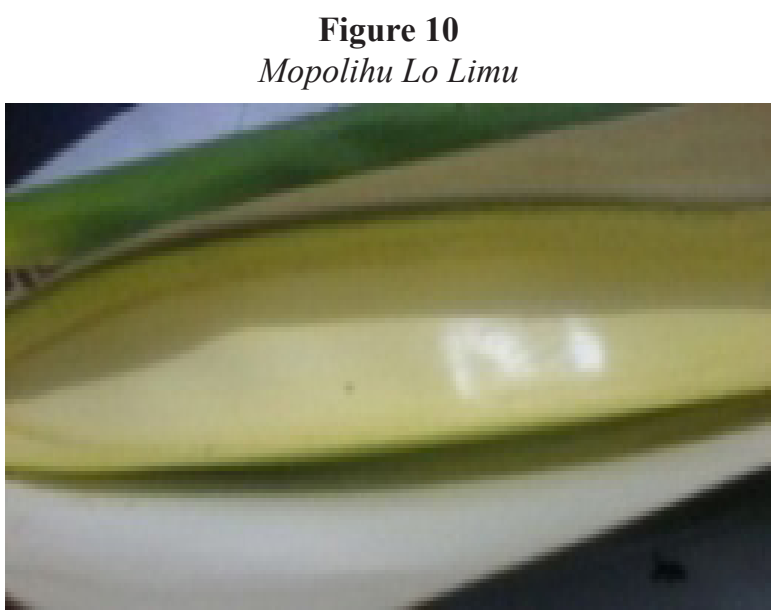

(11) Polohungo To Bunggo 'Croton plugged in Yellow Bamboo'

Bunggo mohelupitu 'seven piece of yellow bamboo' each is coated with doi tala' a ngopita 'one coin' and covered or plugged up with polohungo 'croton', tabongo meela wau tabongo moputio 'red cordyline and white cordyline' and filled with taluhu moonu 'kaffir lime water' (see Figure 9) [E]-[R].

Polohungo and tabongo plants have particular meanings for Gorontalo tribe because every house planted with polohungo and tabongo in front of the house means that among the occupants of the house there is a girl or several girls or virgins [C1]-[O1]. Polohungo planted in front of the house serves as a deterrent if there is one who has bad intention to the occupant of the house [C2]-[O2]. The form of the sign is [R] between E and C1,2 (E-R1-C; E-R2-C). The development towards the secondary or connotative occurs in E-R-C. If polohungo to bunggo is $[\mathrm{R}]$ and $[\mathrm{O}]$ refers to the analysis of $[\mathrm{C} /$ $\mathrm{O} 1,2]$, such process of sign interpretation is called symbol, because the relationship between [R ] and $[\mathrm{O}]$ is conventional $[\mathrm{I}]$. It can be concluded that the form of polohungo to bunggo sign [Sn] does not 
have meaning at the first-denotative (primary) level or icon, but has meaning at the second-connotative (secondary) level or symbol.

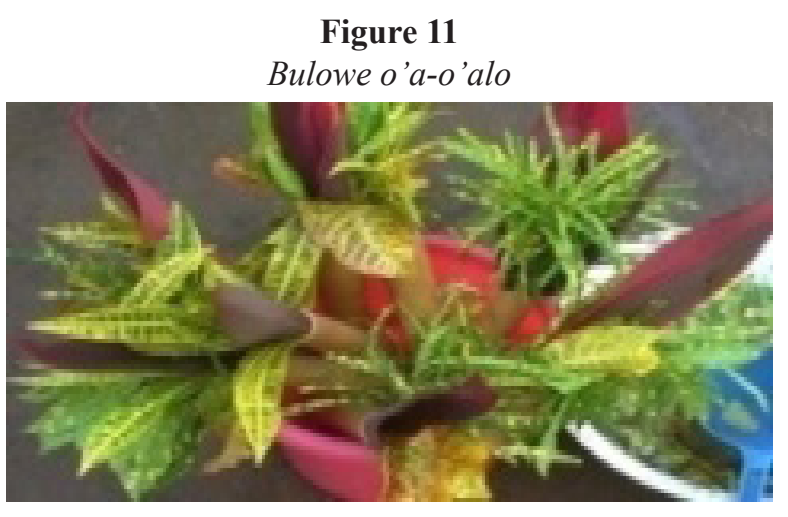

\section{(12) Bulowe 'Arecanut's flowers'}

Bulowe [E]-[R]. Bulowe has fragrance property and is also useful for medicines. Bulowe $o$ 'a-o'alo 'open arecanut' (see Figure 11), [C1][O1]. Bulowe hu'uhu'umo 'closed arecanut' (see Figure 12). Through bulowe hu'uhu'umo, the future of circumcised child can be found out such as mate, fortune, and fate [C2]-[O2]. In a girl, it is expected that she can follow the nature of bulowe, having a true fragrance. The true fragrance in a broad sense, is the beauty of both physical and mental [C3]. The form of the sign becomes [R] between E and C1,2,3 (E-R1-C; E-R2-C; E-R3-C). The development towards the secondary or connotative occurs in E-R-C. If bulowe is $[\mathrm{R}]$ and $[\mathrm{O}]$ refers to on the analysis of [C/O1], the meaning of the sign, it is called an icon, because the relationship between the $[R]$ and $[\mathrm{O}]$ show identity [I]. If [O] refers to the analysis $[\mathrm{C} / \mathrm{O} 2,3]$, such process of sign interpretation is called symbol, because the relationship between $[\mathrm{R}]$ and $[\mathrm{O}]$ is conventional [I]. It can be concluded that the form of bulowe sign [Sn] has meaning at the first-denotative (primary) level or icon, and meaning at the second-connotative (secondary) level or symbol.
Figure 12

Bulowe hu'uhu'umo

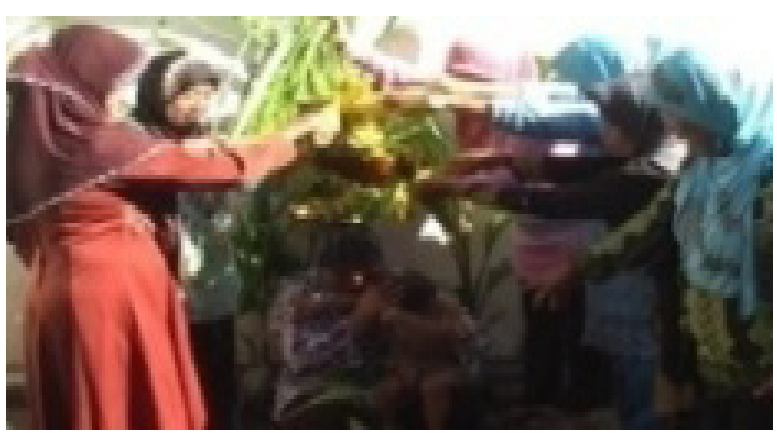

\section{(13) Putito Malua Bohu 'New Egg'}

Putito Malua Bohu 'new eggs' is an affirmation of what is contained in bulowe above, which is about the fate of the child for whom the ceremony is held. There is an event that the egg is broken and then placed on the child's right palm and then moved to the left palm, alternately seven times. (See Figure 13) [E] - [R]. There is a hint inside the egg that this child when the child gets mature sooner or later get amate, even a sign indicating that she will get married more than once or never get married. This sign is called mato lo putito 'eye of the egg' contained in the yolk [C][O]. Mato lo putito usually appears more than one and sometimes does not appear, so that the forecast in the egg emerges [E1]-[R1]. If mato lo putito appears more than one, it shows that the child is likely to get married more than once [C1]-[O1]. If mato lo putito appears but is located on the edge of the yolk, it will show the child will get married to a man who come from a family that is not closely related with the child [C2]-[O2]. If mato lo putito does not appear, it indicates that the child is not likely to get married [C3]-[O3]. If putito is broken in the hands of the child for whom the ceremony is held and the white is mixed with the yolk, it is the sign that child's life in the future is not good, because she cannot distinguish between good and bad [C4]-[O4]. On the contrary, if putito is broken and the white is separated from the yolk, the child is able to differentiate between good and bad, which belongs to her rights and which does not, and indicates that this child will get married soon and have good fortune [C5]-[05]. Putito malu'a bohu symbolizes purity or virginity [C6][O6]. The form of the sign becomes [R] between 
$\mathrm{E}$ and $\mathrm{C}$ and $[\mathrm{R}$ ] between $\mathrm{E} 1$ and $\mathrm{C} 1,2,3,4,5,6$ R-E (E-R-C)C- E (E-R1-C; E-R2-C; E-R3-C; E-R4-C; E-R5-C; E-R6-C). The development towards the secondary or connotative occurs in E-R-C; E-R-C1,2,3,4,5,6. If putito malu'a bohu is $[\mathrm{R}]$ and $[\mathrm{O}]$ refers to the analysis of $[\mathrm{C} / \mathrm{O}]$ above, such process of sign interpretation is called index, because the relationship between $[\mathrm{R}]$ and [O] refers to the source of mato lo putito as a customary tradition [I]. If mato lo putito is [R], $[\mathrm{O}]$ refers to the analysis [C/O1,2,3,4,5,6], such process of sign interpretation is called symbol, because the relationship between $[\mathrm{R}]$ and $[\mathrm{O}]$ is conventional [I]. It can be concluded that the form of putito malu'a bohu sign [Sn] has meaning at the first-denotative (primary) level or index, and meaning at the second-connotative (secondary) level or symbol.

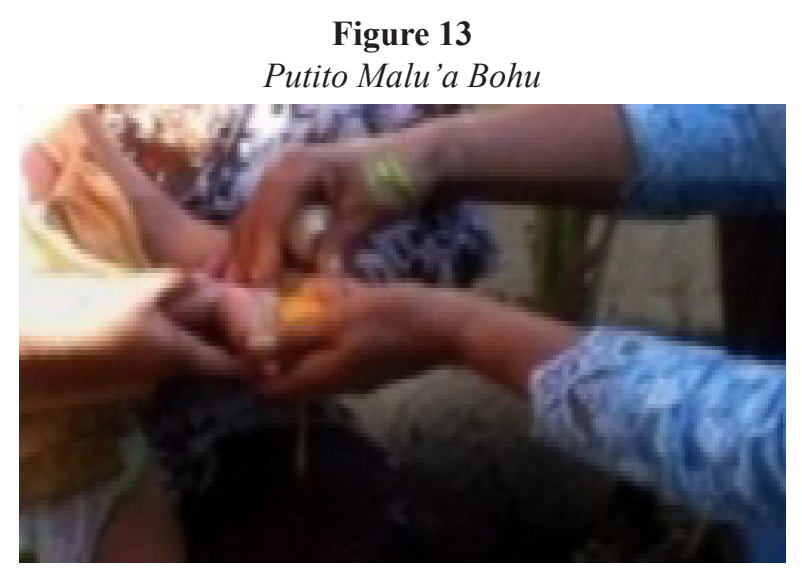

\section{(14) Dudangata 'Coconut Grater'}

According popoli lomongopanggola 'language of the ancestor', hiyambola dudangata o bilulo'a o ayuwa 'even a coconut grater has place and behavior' [E]-[R]. This expression means that dudangata has a designated spot and never move, i.e. kitchen [C1] - [O1].

Dudangata is also equated with woman because they have always to deal with the kitchen. For example, a woman carries out duties and obligations as a wife or mother of children by taking care their clothes and food. This work is always associated with the kitchen. The message conveyed by this expression is that a woman should have a definite place and good behavior, and be useful for other human beings (see Figure 14) [C2] - [O2]. Dudangata is always sought by people who have coconut because coconut without dudangata will not work, and vice versa [C3]-[O3]. Dudangata is compared with a person with knowledge, people who need such knowledge will definitely look for him wherever he is [C4] - [O4]. Dudangata wau bongosymbolize a tool to eliminate crime and cruelty or injustice, as cutting coconut's hair, the more the coconut is cut, the thinner it is. Similarly, it is expected that as the age increases, the child is able to stay away from despicable disposition [C5][O5]. The form of the sign becomes [R] between $\mathrm{E}$ and $\mathrm{C} 1,2,3,4,5,6$ (E-R1-C; E-R2-C; E-R3-C; E-R4-C; E-R5-C; E-R6-C). The development towards the secondary or connotative occurs in E-R-C; E-R-C1,2,3,4,5,6. If dudangata is [R] and $[\mathrm{O}]$ refers to the analysis of [C/ O1,2,3,4,5,6], such process of sign interpretation is called symbol, because the relationship between [R] and [O] is conventional [I]. It can be concluded that the form of dudangata sign [Sn] does not have meaning at the first-denotative (primary) level or index, but has meaning at the second-connotative (secondary) level or symbol.

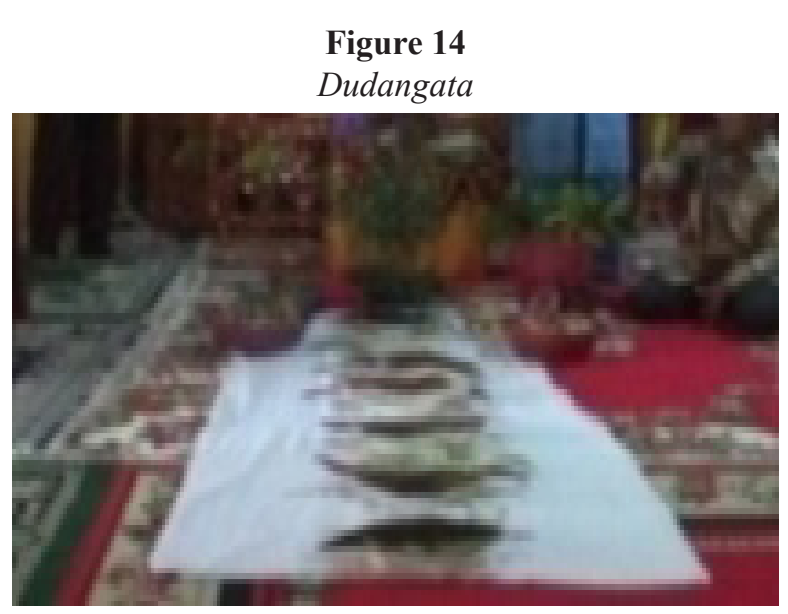

\section{DEVICES IN THE STAGE OF MOPOHUTA'A TO PINGGE 'STEPPING ON PLATES' \\ (15) Pingge mohelupitu 'seven plate'}

Pingge mohelupitu are placed on wumbato moputi'o 'white cloth mat' as seen in Figure 15 [E]-[R]. Every pingge 'plate' is filled with doi tala'a ngopita wau pitulopata polohungo 'one coins and seven croton leaves'. Pingge mohelupitu symbolizes worldly matterssuch as wealth, high position, and [C1]-[O1]. In the worldly life there are many things that cause people to be good 
or bad. Therefore, the seven plates are stepped, meaning that things are not good should be avoided in this life [C2]-[O2]. The form of the sign becomes [R] between E and C1,2 (E-R1-C; E-R2-C). The development towards the secondary or connotative occurs in E-R-C; E-R-C1. If pingge mohelupitu is $[\mathrm{R}]$ and $[\mathrm{O}]$ refers to the analysis of $[\mathrm{C} / \mathrm{O} 1,2]$, such process of sign interpretation is called symbol, because the relationship between $[\mathrm{R}]$ and $[\mathrm{O}]$ is conventional $[\mathrm{I}]$. It can be concluded that the form of pingge mohelupitu sign [Sn] there does not have meaning at the first-denotative (primary) level or index, but has meaning at the second-connotative (secondary) level or symbol.

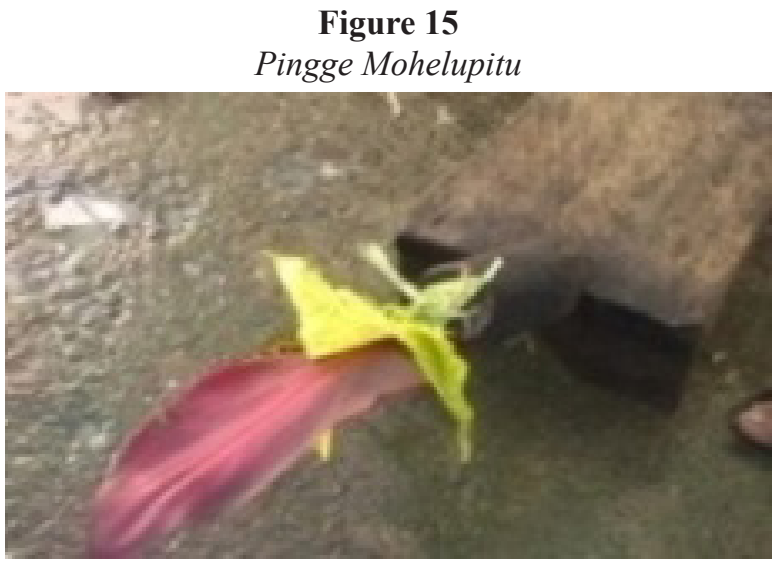

(16) Pale Tiubongo wau Binte 'Unhulled Rice and Corn'

Pale ti'ubongo wau binte 'unhulled rice and corn' as shown in Figure 16 and 17 [E]-[R] are daily human needs [C1] - [O1].Why these two objects are devices in Pohutu Aadati Lihu Lo Limu? It is based on the myth of the story of Prophet Adam when he was separated from Eve for forty days. When the Prophet Adam met with a stone that looked like the form of female genitalia, lust drove Adam until he pilotuhuta 'ejaculated' on the stone, then with the power of God a girl came out of the stone. According to the story, the girl was killed by Adam himself, because of Eve's jealousy. The girl was named Siti Mayakini. After Siti Mayakini was killed, and died, she was immediately buried
[E1]-[R1]. According to the story, on the grave of Siti Mayakini two kinds of grass grew, one kind of grass grew into a coconut tree (see Figure 8) and another remained growing as grass but had three flowers; one flower fell to the ground and then grew into a kind of grass called paawota/huhuloa li buumbu (see Figure 18, 19); and one flower grew into pale and one flower into binte (see Figure 16, 17). The original name of Siti Mayakini was Siti Intani 'Siti Intan' because she was from a stone, and so that based on pale wau binte her name became intani puti 'white diamond' and puti iintani 'as white as diamond' [C1]-[O1]. Stepping on the plate containing pale wau binte is a symbol of hard work to make a living [C2]-[O2]. The form of the sign becomes $[R]$ between $\mathrm{E}$ and $\mathrm{C}(\mathrm{E}-\mathrm{R} 1-\mathrm{C})$ [R] between E1 da C1,2 (E-R1-C; E-R2-C). The development of meaning towards the secondary or connotative occurs in E-R-C; E-R- C1,2. If pale wau binte is $[\mathrm{R}]$ and $[\mathrm{O}]$ refers to the analysis of $[\mathrm{C} / \mathrm{O}]$ above, such process of sign interpretation is called symbol, because the relationship between [R] and [O] is conventional [I]. If Ti Siti Mayakini is $[\mathrm{R}],[\mathrm{O}]$ refers to the analysis of $[\mathrm{C} / \mathrm{O} 1,2]$, such process of sign interpretation is called index because the relationship between $[\mathrm{R}]$ and $[\mathrm{O}]$ is direct and causative [I]. It can be concluded that the form of pale wau binte sign [Sn] has meaning at the first-denotative (primary) level or icon or index, and meaning at the second-connotative (secondary) level or symbol.

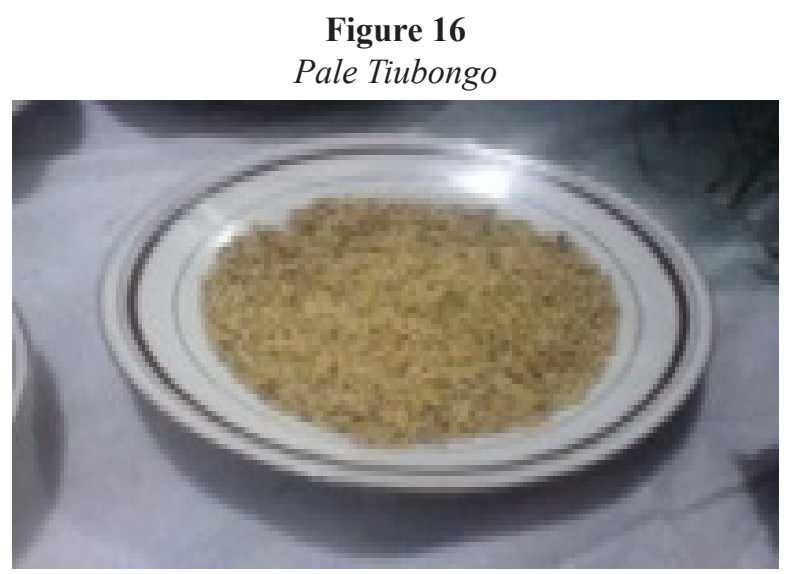




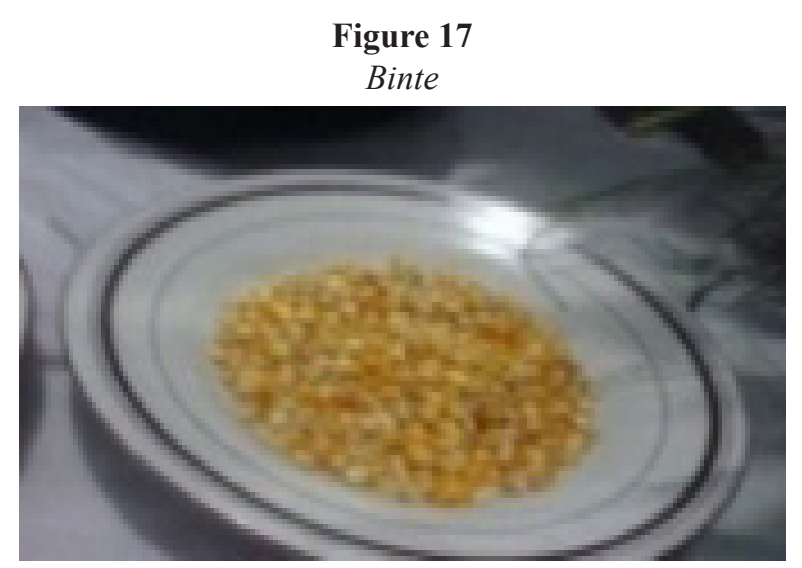

(17) Po'otoheto wau Paawota/Huhuloa Li Buиmbu 'Hard Grass and Elephant Grass'

Both types of grass is packed in a single plate along with the soil. Both grasses have different properties, one is hard and another is weak [E]-[R]. Paawota/huhulo'a li buumbu is a kind of elephant grass that is weak, grows fast and productively symbolizing woman's gentle nature but can develop descendants or childbirth [C1]-[O1]. A woman can also take hard and soft attitudes as the hardness and softness of the two types of grass. Hard in principle and soft in speaking and acting (see Figure 1819) $[\mathrm{C} 2]-[\mathrm{O} 2]$. The form of the sign becomes [R] between E and C (E-R1-C; E-R2-C). The development towards the secondary or connotative occurs in E-R- C1,2. If Paawota/huhulo'a li buumbu is [R] and [O] refers to the analysis of [C/ $\mathrm{O} 1,2]$, such process of sign interpretation is called symbol, because the relationship between $[R]$ and $[\mathrm{O}]$ is conventional [I]. It can be concluded that the form of paawota/huhulo'a li buumbu sign [Sn] does not meaning at the first-denotative (primary) level of icon or index, but has meaning at the second-connotative (secondary) level or symbol.

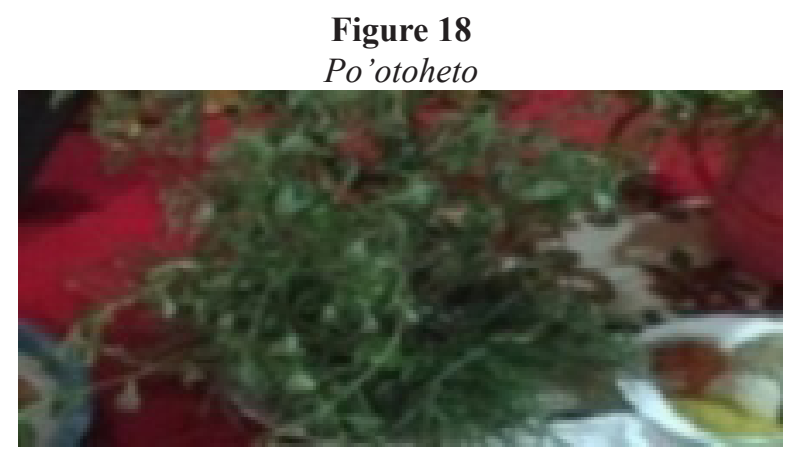

Figure 19

Paawota/Huhulo'a Li

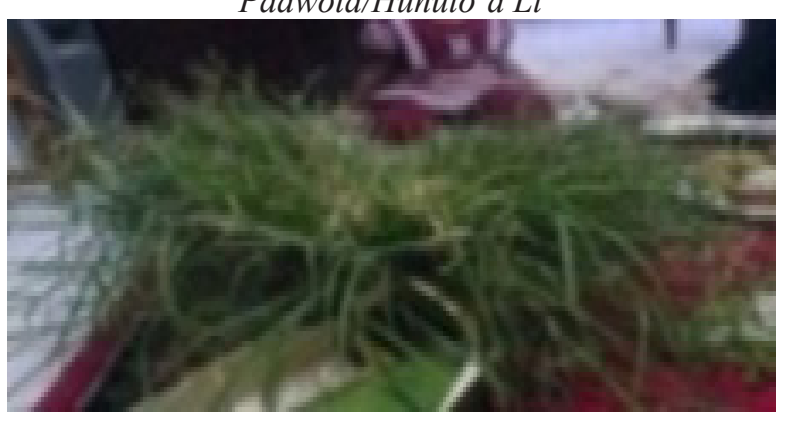

(18) Bakohati 'Box of Heart/Conscience'

Bakohati 'Box of heart/conscience' has five angles, containing traditional cosmetics such as scrubs and powders to make body smooth, golden yellow, and there are seven pieces (see Figure 19) [E]-[R]. In terms of religious perspective, bakohati represents a box of soul.

The shape of five angles symbolizes the five principles of Gorontalo tribe, the five pillars of Islam and also five-time praying; the content symbolizes a refined character and a clean soul; golden yellow symbolizes the glory of the country; and the number seven symbolizes the seven human dignity: (a) Nafsu/ amarah; (b) Lauwama; (c) Mulhima; (d) Mutmainnah:: which is a practice; (E) Radliah; (F) Maraadliah; and (g) Kaamilan. The five principles of Gorontalo community are: (a) Lipu poduluwalo 'the country is defended and protected; (B) Bangusa taalalo 'the country is guarded; (C) Batanga pomaya to lipu 'willing to sacrifice for the country'; (D) Upango potombulu 'possessions are offered; and (e) Nyawa podungalo 'life is at stake' [C] - [O]. The form of the sign is $[\mathrm{R}]$ between $\mathrm{E}$ and $\mathrm{C}(\mathrm{E}-\mathrm{R}-\mathrm{C})$. The development towards the secondary or connotative occurs in E-R-C. If bakohati is [R] and [O] refers to the analysis of $[\mathrm{C} / \mathrm{O}]$, such process of sign interpretation is called symbol, because the relationship between $[\mathrm{R}]$ and $[\mathrm{O}]$ is conventional [I]. It can be concluded that the form of bakohati sign [Sn] does not have meaning at the firstdenotative (primary) level or icon or index, but has meaning at the second-connotative (secondary) level or symbol. 


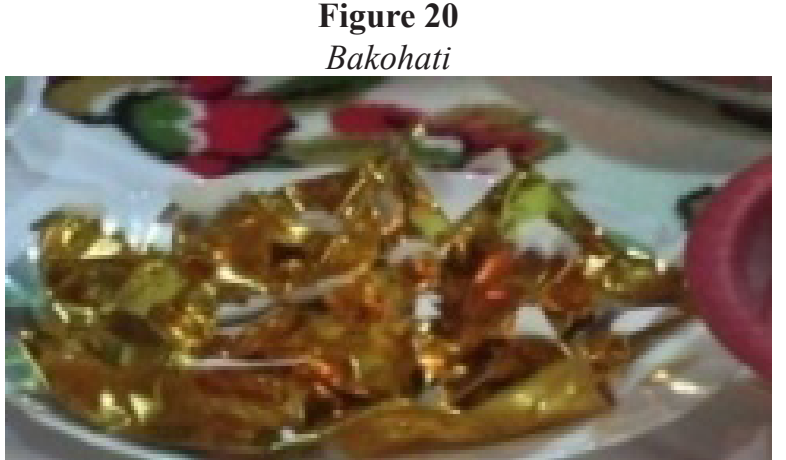

(19) Toyungo wau wumbato 'umbrella and cloth' Toyungo is used the child when he steps on the plate containing materials that have been prepared and walks seven times [E]-[R]. Toyungo is symbolizes the oneness of Allah SWT. Only God can protect all living beings on earth. Protection and help are only from Allah SWT. (See Figure 23) $[\mathrm{C}]-[\mathrm{O}]$. Wumbato is a white cloth measuring two meters [E1]-[R1]. Wumbato is a symbol in implementing custom based on purity. Toyungo wau wumbato 'umbrella and cloth' symbolize protection and foothold [C]-[O]. The form of the sign becomes [R] between $\mathrm{E}$ and $\mathrm{C}(\mathrm{E}-\mathrm{R}-\mathrm{C}) ;[\mathrm{R}]$ between $\mathrm{E} 1$ and $\mathrm{C}$ (E-R2-C). The development towards the secondary or connotative occurs in $\mathrm{E}$ (E-R-C). If toyungo wau wumbato is [R] and [O] refers to the analysis of $[\mathrm{C} / \mathrm{O}]$, such process of sign interpretation is called symbol, because the relationship between $[\mathrm{R}]$ and $[\mathrm{O}]$ is conventional [I]. It can be concluded that the form of toyungo wau wumbato sign [Sn] does not have meaning at the first-denotative (primary) level or icon or index, but has meaning at the second-connotative (secondary) level or symbol.

Figure 21

Toyungo wau Wumbato

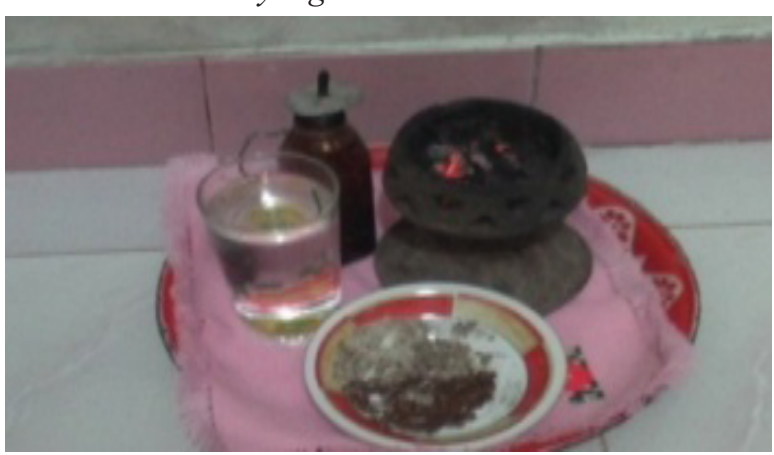

\section{(20) Hulante 'a set of materials'}

One tray containing seven bowls of rice, seven eggs, seven nutmeg, seven cloves, seven limes, and seven coins each worth Rp 100.- or 10 cents is called hulante (see Figure 22) [E]- [R]. Hulante symbolizes human life both physically and spiritually. $[\mathrm{C}]-[\mathrm{O}]$. The form of the sign becomes [R] between $\mathrm{E}$ and $\mathrm{C}(\mathrm{E}-\mathrm{R}-\mathrm{C})$. The development towards the secondary or connotative occurs in E-R-C. If hulante is [R] and [O] refers to the analysis of $[\mathrm{C} / \mathrm{O}]$, such process of sign interpretation is called symbol, because the relationship between $[\mathrm{R}]$ and $[\mathrm{O}]$ is conventional [I]. It can be concluded that the form of hulante sign [Sn] does not have meaning in the firstdenotative (primary) level or icon or index, but has meaning at the second-connotative (secondary) level or symbol.

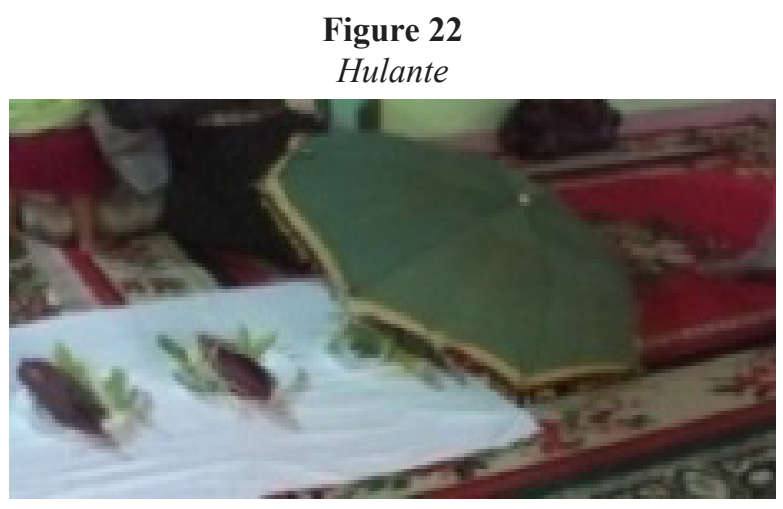

(21) Pollutube, Totabu/Alama, Taluhu Ngohalati 'Place for Cinder, Incense/Benzoin, A Glass of Water'

The device in Figure 23 is used when performing mongadi shalawati 'a prayer for prophet/ a prayer of thanksgiving' and each has a function [E]-[R].Pollutube 'place for cinder' is used to put the cinder; totabu/alama 'incense or benzoin' serves as an air freshener; taluhu ngohalati serves as a sedative for the child for whom the ceremony is held because the child to be circumcised must be terrified [C1]-[O1]. This device also symbolize four elements that are in earth: water, fire, soil, and wind. Wind and fire appear when totabu/alama burned in cinder causing smoke and through the smoke the wind is visible. Soil appears in the pollutube which is made of earth. Water is represented with a 
glass of water that is put together with other devices in the tray [C2]-[O2]. The form of the sign becomes [R] between $\mathrm{E}$ and $\mathrm{C} 1,2$ (E-R1-C; E-R2-C). The development towards the secondary or connotative occurs in E-R- C1,2. If pollutube, totabu/alama, taluhu ngohalati are[R] and [O] refers to the analysis of [C/O1], such process of sign interpretation called index, because the relationship between [R] and [O] is direct and causative [I]. If [O] refers to the analysis of [C2], such process of sign interpretation called symbol, because the relationship between $[\mathrm{R}]$ and $[\mathrm{O}]$ is conventional [I]. It can be concluded that the form of pollutube, totabu/alama, taluhu ngohalati sign [Sn] has meaning at the first-denotative (primary) level or index, and has meaning at the secondconnotative (secondary) level or symbol.

Figure 23

Pollutube, Totabu/Alama, Taluhu Ngohalati wau Tohe

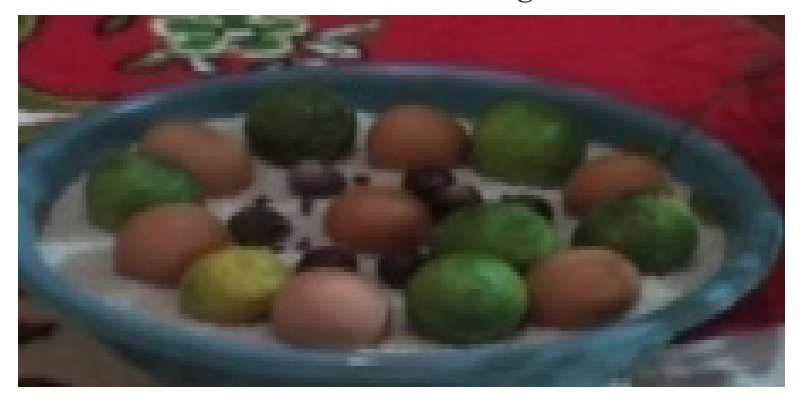

\section{CONCLUSION}

Based on the above explanation, sign and sign system contained in Pohutu Aadati Lihu Lo Limu device is sign and sign system based on the relationship between expression and content (E-R-C) and based on the relationship between reality and the basic types such icon, index, and symbol $([\mathrm{R}]-[\mathrm{O}]-[\mathrm{I}]$. In the sign and the sign system of $[\mathrm{E}]-[\mathrm{R}]-[\mathrm{C}]$ there are forms like $[\mathrm{R}]$ between $\mathrm{E}$ and $\mathrm{C}$, which means the development of meaning and the change in direction towards the secondary or connotative $[\mathrm{C}]$ occurs only once in the expression $[\mathrm{E}]=(\mathrm{E}-\mathrm{R}-\mathrm{C})$. If the development of meaning and the change towards the secondary or connotative $[\mathrm{C}]$ occurs several times $(6 \mathrm{x})$ in the expression [E], the form becomes the relation [ R] E(E-R1-C, E-R2-C, E-R3-C, E-R4-C, E-R5-C, and E-R6-C) C. Such development of meaning of sign and sign systems form occur both at the first-primary (denotative) level and at the second -secondary (connotative) level which can repeat several times in [E]. it can be said that the development of meaning at the first-primary (denotative) level is synonymous with the form of index and icon and the development of the meaning at the second- secondary (connotative) level is synonymous with the form of symbol or conventional form.

\section{REFERENCES}

Barthes, Roland. (1980) Elements of Semiology. New York: Hill and Wang

(2007) Petualangan Semiologi. Translated by Stephanus Anwar Herwinarko. Yogyakarta: Pustaka Pelajar

Eco, Umberto. (2009) Teori Semiotika. Translated by Inyiak Ridwan Muzir. Yogyakarta: Kreasi Wacana.

Hawkes, Terence. (1978) Strukturalism \& Semiotics. London: The Chaucer Press

Hoed, Benny H. (2014).Semiotik \& Dinamika Sosial Budaya. Jakarta: Komunitas Bambu.

Innis, Robert E. (1985) Semiotics An Introductory Anthology. Indiana University Press. Bloomington.

Miles, Matthew B. \& A. Michael Huberman. (2009) Analisis Data Kualitatif Buku Sumber Tentang Metode-Metode Baru. Jakarta: UI-Press

Pradopo, Rachmat Djoko. (1998)."Semiotika: Teori, Metode dan Penerapannya" in Jurnal Humaniora Volume11, No. 1, Januari - April 1999, pp $76-84$.

Santosa, Puji. (1990) Ancangan Semiotika dan Pengkajian Susastra. Bandung: Angkasa

Sassure, Ferdinand de. (1988)Pengantar Linguistik Umum (translated by Rahayu S.Hidayat). Payot,Paris

Spradley, James P. (1980) The Ethnographic Interview. New York: Rinehart and Winston 